\title{
Dynamics of nutrient and phytoplankton in Epe Lagoon, Nigeria: possible causes and consequences of reoccurring cyanobacterial blooms
}

\author{
Sandra Chinwendu Akagha' ${ }^{1}$. Dike Ikegwu Nwankwo ${ }^{1} \cdot K^{2}$ dong Yin ${ }^{2}$
}

Received: 16 May 2019 / Accepted: 30 March 2020 / Published online: 16 April 2020

(c) The Author(s) 2020

\begin{abstract}
The impact of environmental variables and processes of nutrient enrichment on phytoplankton community at Epe lagoon was studied for 18 months (November 2012-April 2014). Two cyanobacterial bloom incidences were observed in the two dry seasons during this period. Rainfall pattern regulated nitrogen limitation which triggered cyanobacterial bloom development and influenced the bloom duration. Nutrient-laden influx from agricultural practices accounted for the increase in nitrate, phosphate and the relatively low silicate. Hypoxic conditions during the two bloom episodes reflected the vulnerability of this lagoon ecosystem. The cyanobacterial blooms were dominated by potentially toxic species; Anabaena circinalis, A. flos-aquae, A. limnetica and A. spiroides. A comparison of ambient nutrient ratios with the Redfield ratio $(\mathrm{N} / \mathrm{P} / \mathrm{Si}=16: 1: 16)$ showed clear temporal variations that coincided with phytoplankton dynamics and the bloom regime. Low N/P ratios were recorded during the first 8 months, and there was a shift to higher ratios during the subsequent 8 months, followed by low N/P ratios in the last 2 months. Higher silicate values coincided with decreased cyanobacterial biomass, cyanobacteria bloom collapse and proliferation of diatoms during the first annual cycle. Cyanobacterial abundance exceeded the alert level 1 and almost reached alert level 2 which call for continuous environmental monitoring and management of coastal waters.
\end{abstract}

Keywords Anabaena $\cdot$ Bloom $\cdot$ Cyanobacteria $\cdot$ Epe lagoon $\cdot$ Nutrient enrichment $\cdot$ Phytoplankton

\section{Introduction}

Phytoplankton form the base of aquatic food webs (Sommer 1989; Arrigo 2005) and are important biological component of marine ecosystems and biogeochemical cycles (Malone 1977; Litchman 2007; Litchman et al. 2015). Their excessive growth can cause significant threat to biodiversity and ecosystem functioning as in the case of toxic algal blooms (HABs) (Paerl and Huisman 2008). HABs occur naturally because of increased water temperature and inorganic nutrients (phosphate, ammonium and nitrate) (Carmichael 1997; Hitzfeld et al. 2000; Wetzel 2001). Global reports on algal blooms have increased because of human activities resulting

Sandra Chinwendu Akagha

sandraakagha@gmail.com

1 Department of Marine Sciences, University of Lagos, Akoka, Nigeria

2 School of Marine Science, Sun Yat-Sen University, Guangzhou 510275, China from elevated nutrient loadings (Paerl and Whitall 1999; Van Dolah 2000; Anderson et al. 2002) and water flow modifications (Ferreira et al. 2005; Edwards et al. 2006). HABs result in food web alterations (Jackson 2001) and dominance of introduced species (Hallegraeff and Bolch 1992; Vanderploeg et al. 2001).

Toxic cyanobacterial blooms can potentially serve as signs or ecological indicators of changes in aquatic ecosystem integrity (Jeppesen et al. 1997; Sanchis et al. 2002; Willame et al. 2005; Carmichael 2008; Peretyatko et al. 2010). It is important to identify and understand what triggers bloom events to enable prediction, surveillance and management strategies for bloom occurrences. The relationships among hydrologic discharge (flushing and residence time), verti$\mathrm{cal} /$ horizontal salinity and thermal gradients, rainfall and drought, wind and tidal mixing determine the frequency, severity, spatial and temporal extent of bloom events in coastal ecosystems (Paerl 2006).

Oxygen depletion in aquatic ecosystem can result from algal blooms. Harmful algal blooms reduce the aesthetic value of coastal and aquatic environment which causes

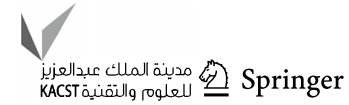


economic loss from ecotourism, fisheries resources and human health threat (Kevin et al. 2003). Human health threat occur from the consumption of shellfish or fish contaminated with cyanobacterial toxins. Shellfish such as clams, mussels and oysters rapidly accumulate algal toxins in their tissues because they filter large volume of water. Cases of HAB-related neurotoxic shellfish poisoning (NSP), paralytic shellfish poisoning (PSP), amnesic shellfish poisoning (ASP), diarrhetic shellfish poisoning (DSP) and saxitoxin puffer fish poisoning (a finfish poisoning) have been reported (Van Dolah 2000).

Blooms can produce toxins (e.g., microcystin) which are released by cyanobacteria, diatoms and dinoflagellates (Paerl and Whitall 1999; Hitzfeld et al. 2000; Wetzel 2001; Anderson et al. 2002; Rabalais and Nixon 2002). Extensive study of population dynamics of cyanobacteria in relation to environmental factors (light, temperature, nutrient, $\mathrm{pH}$, mixing or zooplankton grazing) have been documented (Downing et al. 2001; Paerl and Otten 2013; Fernández et al. 2015). Cyanobacteria can outcompete other algal groups because of their resistance to zooplankton grazing, buoyancy and nitrogen fixing ability by heterocystous forms (Graham and Wilcox 2000; Reynolds 2006). In addition, cyanobacteria can thrive in $\mathrm{CO}_{2}$-deficient and low-pH conditions in aquatic ecosystem (Shapiro 1973; 1997; Sandrini et al. 2016; da Silva Brito et al. 2018). The frequency of eutrophic events has increased over the last several decades in many coastal ecosystems where blooms of phytoplankton are particularly affected by riverine discharge (Paerl et al. 2018). For instance, bloom incidences have been reported in Chesapeake Bay (Officer et al. 1984), the northern Adriatic Sea (Justic et al. 1987), the Baltic Sea (Andersson and Rydberg 1988), Neuse River Estuary (Paerl 2006), Pearl River Estuary (Yin and Harrison 2008), Kopački Rit floodplain (Mihaljevic and Stevic 2011), South African inland waters (Matthews and Bernard 2015), Wadden Sea (Vogt et al. 2017), Eurasian Arctic and Hypoarctic large River Estuaries (Davydov and Patova 2017) and Lake Taihu, China (Li and Qin 2019).

In recent years, the south-west coastal Nigeria is one of the fastest developing regions in West Africa. Epe lagoon boarders the eastern section of the largest metropolitan city (Lagos) in West Africa. Lagos consists of over 21 million inhabitants (Ojolowo and Onifade 2016) with associated rapid economic development and coastal degradation by human activities. Epe lagoon is connected to the Lagos lagoon and, hence, receives large loads of anthropogenic nutrients from increased agriculture, fish farming, poorly treated sewage effluent (Onyema et al. 2004; Akagha 2017) and domestic/industrial waste discharge (Chukwu and Nwankwo 2004). In Nigeria, the incidences of cyanobacteria blooms have been documented over the past three decades. Blooms of Anabaena flos-aquae, A. spiroides, Microcystis aeruginosa, M. flos-aquae and $M$. wesenbergii were reported in the Lagos lagoon (Nwankwo 1993; 1996), Microcystis aeruginosa in Iju, Ogun river (Nwankwo 1993), Microcystis sp. in Kuramo lagoon (Nwankwo 1993), Anabaena flos-aquae in Owo river (Nwankwo et al. 1999), Microcystis aeruginosa in Awba reservoir, Ibadan (Akin-Oriola 2003), Microcystis aeruginosa and $M$. wesenbergii bloom in Oyan dam, Ogun state (Adesalu et al. 2016) and the proliferation of Oscillatoria sp. in the Lagos lagoon (Onyema and Nwankwo 2009). These bloom series were reported to cause colouration, anoxia, odour and bad taste of the water in these aquatic ecosystems.

Akagha et al. 2019 documented the presence of a new cyanobacterial species Lagosinema tenuis in the Lagos lagoon which further highlights the ecological relevance of cyanobacterial dominance in tropical African lagoon systems. In this paper, our objectives are to elucidate: (1) environmental variables and phytoplankton dynamics, (2) nutrient dynamics and eutrophication and (3) annual cyanobacterial blooms and associated environmental factors in Epe lagoon through an 18-month investigation of three ecological sites.

\section{Materials and methods}

\section{Study area}

Epe lagoon (Fig. 1) is a tropical water body with a surface area of $243 \mathrm{~km}^{2}$ located at the eastern part of the Lagos lagoon complex (Kusemiju 1988). Epe lagoon is fresh, lotic, non-tidal and sandwiched between Lagos and Lekki lagoons (Nwankwo 1998; Uwadiae 2010). It is connected to the Atlantic Ocean via the Lagos lagoon year round. Epe lagoon is influenced by freshwater input from creek and river inflow (Nwankwo 1998). Riparian vegetation such as Paspalum orbiculare, Raphia hookeri, Elaeis guineensis, Acrostichum aureum, Cocos nucifera and mangroves Rhizophora racemosa, Avicennia nitida are found along the fringing wetland. Notable fauna found in this area are amphipods, oligochaetes, polychaetes, isopods, barnacles, oysters, nematodes, fiddler crabs and migratory birds that feed on exposed biota. The bordering wetland has experienced rapid population growth, agricultural and urban development over the past decade. As a result, anthropogenic activities including domestic waste deposition, fishing, indiscriminate sand mining and inland water transportation are increasing in Epe lagoon. Human influenced sites along the Epe lagoon include the hydrothermal plant at Egbin and agricultural sites on the bordering wetland at Ikosi. In this paper, three sites (Imope, Ikosi and Egbin) were investigated based on their ecological uniqueness and bloom incidences. 


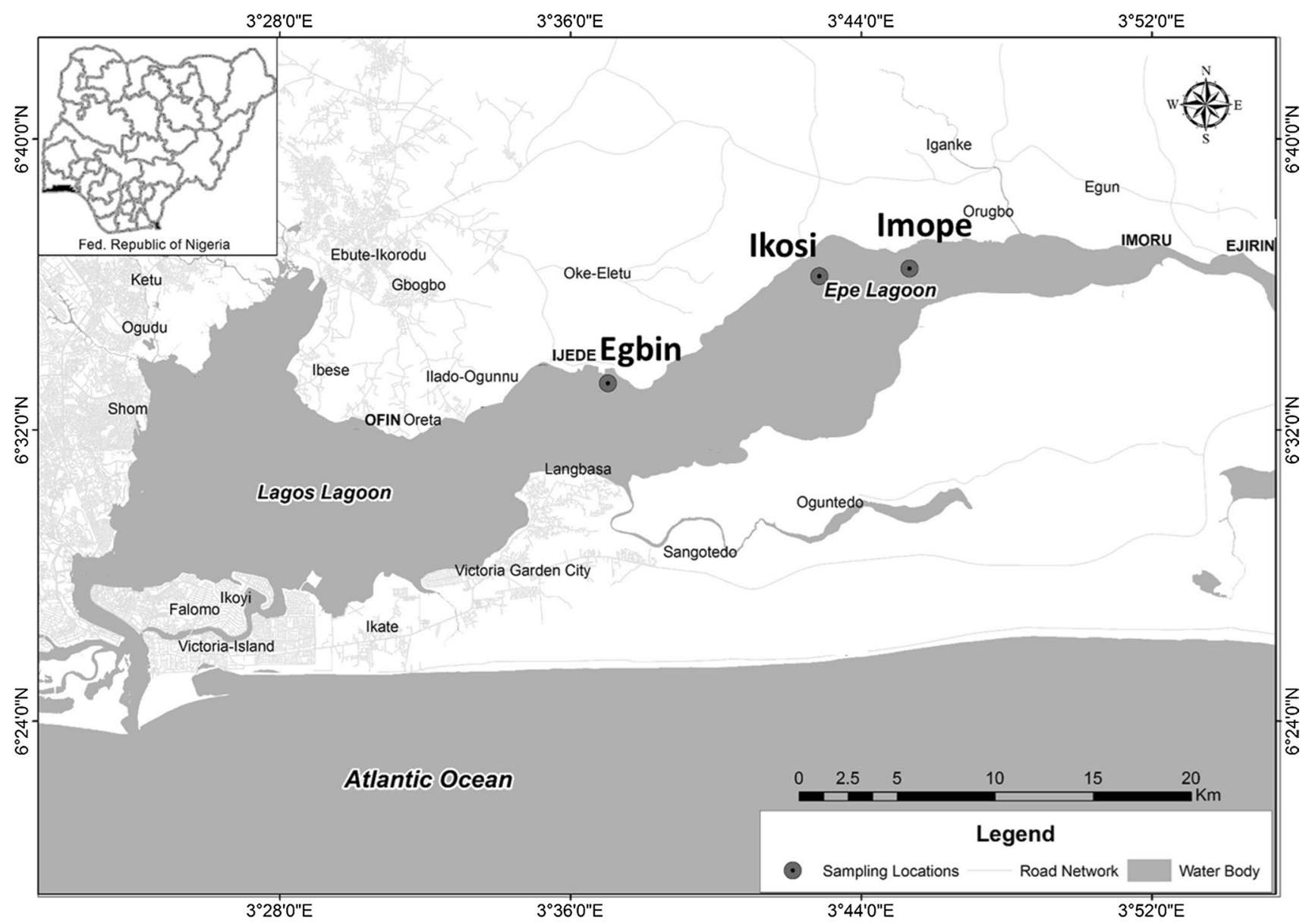

Fig. 1 Map of study area indicating the three sampling sites: Egbin, Ikosi and Imope

\section{Collection of water and phytoplankton samples}

Samples of water and phytoplankton were collected monthly for 18 months (November 2012-April 2014) in the morning. Water samples were collected in a well-labelled 1-L plastic bottle with screw cap and transported in a cooler with ice to the laboratory for chemical analysis. Three $250-\mathrm{ml}$ amber bottles were used to collect water samples for analysis of dissolved oxygen, biological oxygen demand and chlorophyll $a$. Samples for dissolved oxygen were fixed with the Winkler reagent. Phytoplankton samples were collected with a $35 \mu \mathrm{m}$ plankton net tied unto a motorized boat and towed at low speed (4 knots) for $5 \mathrm{~min}$. The plankton net was hauled in and the samples were emptied into a 500-ml well-labelled plastic container with screw cap and fixed with $4 \%$ unbuffered formalin.

\section{Physical and chemical parameters}

Water temperature was measured in situ with a mercury thermometer, and water depths were measured with a calibrated pole. A Philips pH meter (Model PW950) and a hand-held Refractometer (model RHS-10 ATC) were used to determine $\mathrm{pH}$ and salinity, respectively. Total dissolved solids (TDS) were measured with HANNA instrument (HI98311). Total suspended solids (TSS) were measured following standard methods (APHA 2005). Dissolved oxygen was determined by the standard Winkler method, and biological oxygen demand (BOD) was measured after 5 days of incubation. Chemical oxygen demand (COD) was estimated using closed Reflux method (APHA 2005). Chlorophyll $a$ determination was made using the acetone extraction spectrophotometric method (APHA 2005) with detection limits of approximately $1 \mu \mathrm{g} / \mathrm{L}$, which was based on three times the standard deviation of the lowest concentrations of the samples. Rainfall data were provided by the Department of Meteorological Services, Oshodi, Nigeria.

\section{Inorganic macronutrients and nutrient ratio}

Phosphate and nitrate were analysed using ascorbic acid spectrophotometric method and the phenol disulphonic acid method, respectively (APHA 2005). Sulphate and silicate were determined using the standard methods (Strickland and

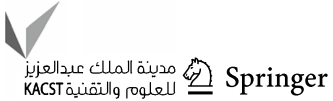


Parsons 1972). To determine the seasonal trend of nutrient (molar) ratios, data were pooled for each season and the average were taken as follows: dry season I (November 2012-February 2013), early wet I (March 2013-June 2013), late wet I (July 2013-October 2013), dry season II (November 2013-February 2014) and early wet II (March 2014-April 2014).

\section{Stoichiometric assessment of nutrient limitation}

Stoichiometric assessment of nutrient limitation was made according to the published criteria (Dortch and Whitledge 1992; Justic et al. 1995a, b; Xu et al. 2008). The ratio of two ambient nutrients was calculated, and the Redfield ratio (Redfield et al. 1963) was applied to predict that: (1) $\mathrm{N}$ limitation occurs when $\mathrm{N} / \mathrm{P}<16: 1$ and $\mathrm{Si} / \mathrm{N}>1: 1$ and an estimated threshold value of $1 \mathrm{mM}$; (2) P limitation was assumed when $\mathrm{N} / \mathrm{P}>16: 1$ and $\mathrm{Si} / \mathrm{P}>16: 1$ with an estimated threshold value of $0.1 \mu \mathrm{M}$; and (3) Si limitation was assumed when $\mathrm{N} / \mathrm{Si}<1: 1$ and $\mathrm{Si} / \mathrm{P}<16: 1$, with an estimated threshold value of $2 \mu \mathrm{M}$. The approach was similar to others, for example, in the Mississippi River estuary (Justic et al. 1995a and in Hong Kong waters where the variations of nutrient stoichiometry in regulating phytoplankton biomass were used (Xu et al. 2008).

\section{Phytoplankton}

The preserved phytoplankton samples were concentrated by allowing cells to settle for at least $24 \mathrm{~h}$ and thereafter decanted. The micro-transect drop count method as described by Lackey (1938) was employed to investigate the phytoplankton species composition and abundance. One drop of each concentrated sample was thoroughly investigated by observing all fields within the cover slip border using an Olympus BX51 binocular microscope with calibrated eye piece at different magnifications $(10 \times$ and $40 \times)$. This was done five times to account for all phytoplankton species in the water samples. The total number of phytoplankton identified was recorded as number of cells per ml. Taxonomy publications including Patrick and Reimer (1966, 1975), Prescott (1961, 1973, 1975, 1979, 1984), Compère (1976, 1977), Komárek and Fott (1983, Round 1981), Vanlandingham (1982), Krammer and Lange-Bertalot (1986, 1988, 1991, 2000), Krammer et al. (1991a), Komárek and Anagnostidis (1998, 2005) and Wolowski and Hindak (2005) were consulted to identify phytoplankton taxa.

\section{Statistical analyses}

Analysis of variance (ANOVA) was used to test the significant differences of each parameter between the sampling sites. The correlation coefficient, $r$ was calculated using
Microsoft ${ }^{\circledR}$ Excel 2015. The statistical test for significance is based on critical values of correlation coefficient, $r$ (Zar 1999).

\section{Results}

\section{Physical and chemical variables}

Rainfalls ranged between 0 and $413.6 \mathrm{~mm}$ during the study period. In January 2013 (bloom episode I), there was no rainfall, but increased to $80.1-132.7 \mathrm{~mm}$ in January and February 2014 (bloom episode II). Water temperature oscillated between 23 and $34{ }^{\circ} \mathrm{C}$ with the minimum recorded in August 2013 (Fig. 2). Total suspended solids and total dissolved solids were between $(4-3166 \mathrm{mg} / \mathrm{L})$ and $(30-5290 \mathrm{mg} / \mathrm{L})$, respectively. $\mathrm{pH}$ was $6.1-7.7$, indicating acidic conditions, while salinity was in the range of $0-5 \%$ (Fig. 2). Dissolved oxygen, BOD and COD were in the range of $2-15 \mathrm{mg} / \mathrm{L}$, $0.5-13 \mathrm{mg} / \mathrm{L}$ and $15-160 \mathrm{mg} / \mathrm{L}$, respectively (Fig. 3). There were no significant differences $(P>0.05)$ in the environmental variables across all the sampling sites except for total suspended solids which was significantly different $(P>0.05)$ across the sampling sites.

\section{Chlorophyll $a$}

Chlorophyll $a$ ranged from $1 \mu \mathrm{g} / \mathrm{L}$ (below the limit of detection) at Imope in February 2013 to $201 \mu \mathrm{g} / \mathrm{L}$ at Ikosi in February 2014 . Chlorophyll $a$ values were higher $(\geq 55 \mu \mathrm{g} / \mathrm{L})$ in the dry months (November 2012-January 2013) at the three sites during the first annual cycle, and higher values $(\geq 153 \mu \mathrm{g} / \mathrm{L}$ ) were recorded at Ikosi during the dry month (January 2014-February 2014) of the second annual cycle (Fig. 3).

\section{Nutrient concentrations and molar ratios}

Nitrate ranged from 1.45 to $20.16 \mu \mathrm{M}$, whereas lower values $(\geq 1.45 \mu \mathrm{M})$ were recorded in January 2013 at all sites. $\mathrm{PO}_{4}, \mathrm{SiO}_{4}$ and $\mathrm{SO}_{4}$ concentrations were $(0.18-18.76 \mu \mathrm{M})$, $(0.03-4.24 \mu \mathrm{M})$ and $(0.10-18.63 \mu \mathrm{M})$, respectively. Nitrate, phosphate and sulphate concentrations showed seasonal trends. Higher values of nitrate were recorded in the wet month $(\geq 2.42 \mu \mathrm{M})$ at the three stations, whereas lower sulphate values $(\leq 4.37 \mu \mathrm{M})$ were observed in the wet season except in March 2013 when values were higher $(\geq 12.08 \mu \mathrm{M})$ at Egbin. $\mathrm{SiO}_{4}$ values were highest at Imope $(\geq 2.31 \mu \mathrm{M})$ in February 2013 and at Ikosi $(\geq 4.24 \mu \mathrm{M})$ in March 2013 (Fig. 3). N/P ratio at the three sampling sites varied seasonally unlike $\mathrm{Si} / \mathrm{N}$ ratio. Low $\mathrm{N} / \mathrm{P}$ ratios $(\leq 4.5: 1)$ were recorded during the first 8 months and shifted to higher ratios $(\geq 16.7: 1)$ during the subsequent 
Fig. 2 Monthly variations in temperature $\left(23-34{ }^{\circ} \mathrm{C}\right), \mathrm{pH}$ (6.1-7.7), salinity (0-5\%o), TSS (4-3166 mg/L) and TDS $(30-5290 \mathrm{mg} / \mathrm{L})$ at the three stations
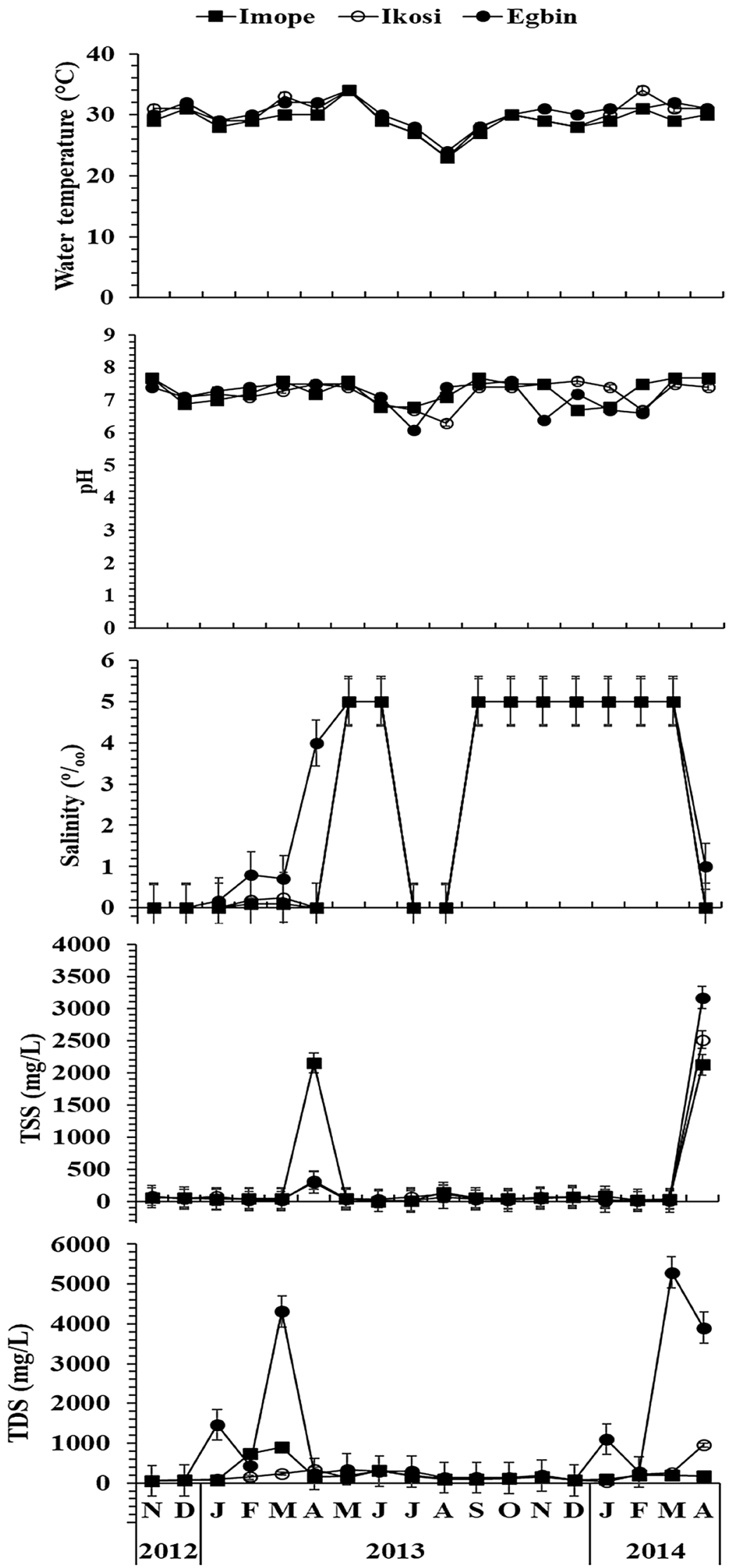

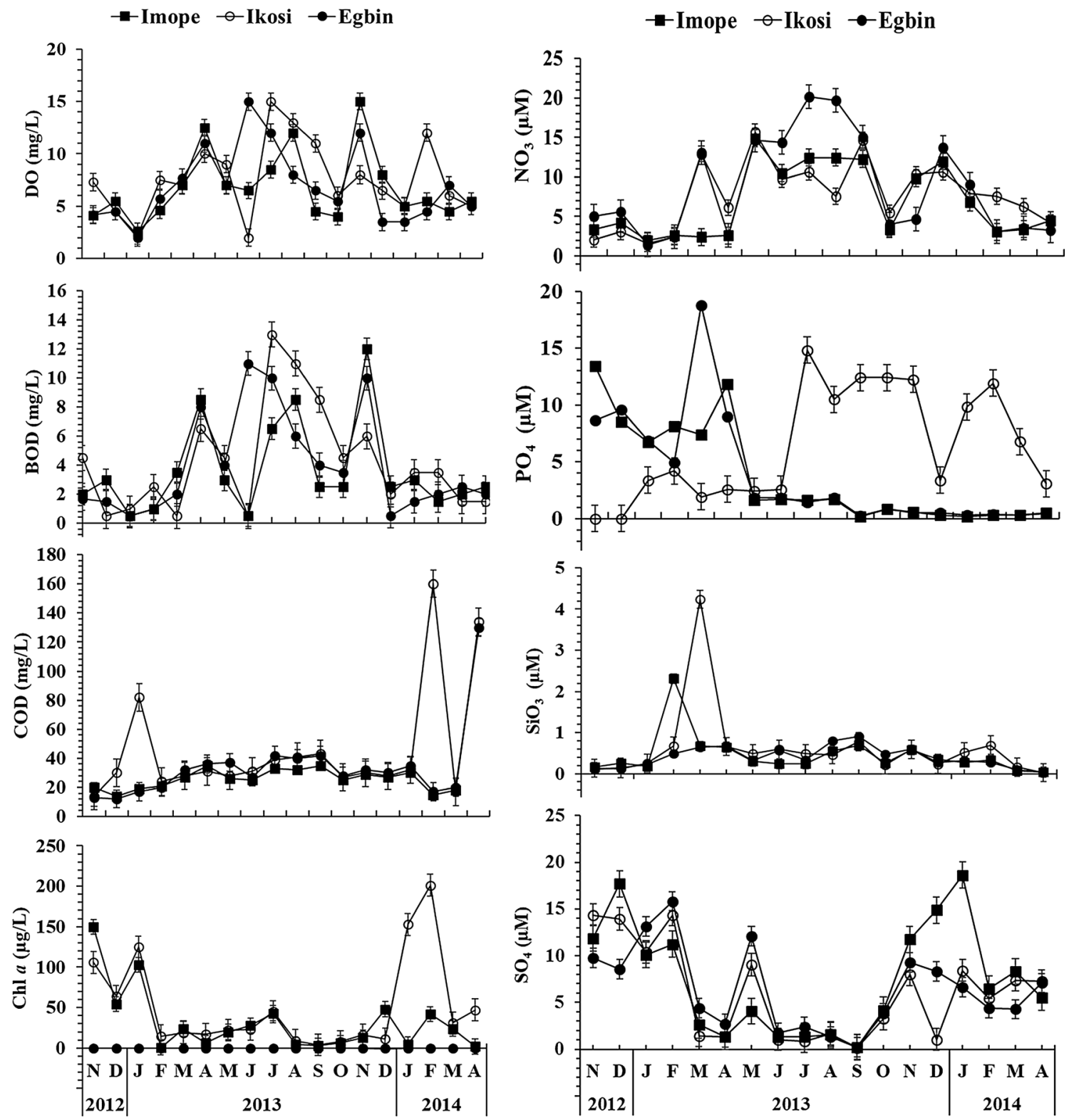

Fig. 3 Monthly variations of water $\mathrm{DO}, \mathrm{BOD}, \mathrm{COD}$, chlorophyll $a$, nitrate, phosphate, silicate and sulphate at the three stations

8 months (late wet I and dry season II), followed by low ratios $(\leq 13.21)$ in the last 2 months at the three sampling sites (Fig. 4). Overall, N/P ratio values were between 0.22-58.23 at Imope, 0.22-48.1 at Ikosi and 0.21-59.4 at Egbin, while Si/N ratios were between 0.01-0.90 at Imope, 0.01-0.33 at Ikosi and 0.01-0.26 at Egbin (Fig. 5). Based on $\mathrm{Si} / \mathrm{N}=1: 1, \mathrm{~N} / \mathrm{P}=16: 1$ and $\mathrm{Si} / \mathrm{P}=16: 1$, there were six different areas characterized by the most limiting nutrients. $\mathrm{NO}_{3}, \mathrm{PO}_{4}$ and $\mathrm{SO}_{4}$ were not significantly correlated with chlorophyll $a$ at Ikosi, except for $\mathrm{SiO}_{3}$ which showed a significant and negative relationship with chlorophyll $a$ (Fig. 6).

\section{Phytoplankton dynamics}

A total of 116 species belonging to 54 genera were recorded during the study, and there were six phytoplankton groups including Bacillariophyceae (40.7\%), Chlorophyceae (30.1\%), Chrysophyceae (0.89\%), Cyanophyceae (20.4\%), Dinophyceae $(0.89 \%)$ and Euglenophyceae $(7.08 \%)$. The centric diatom, Aulacoseira granulata, was the dominant species except in January 2013, 2014 and February 2014 

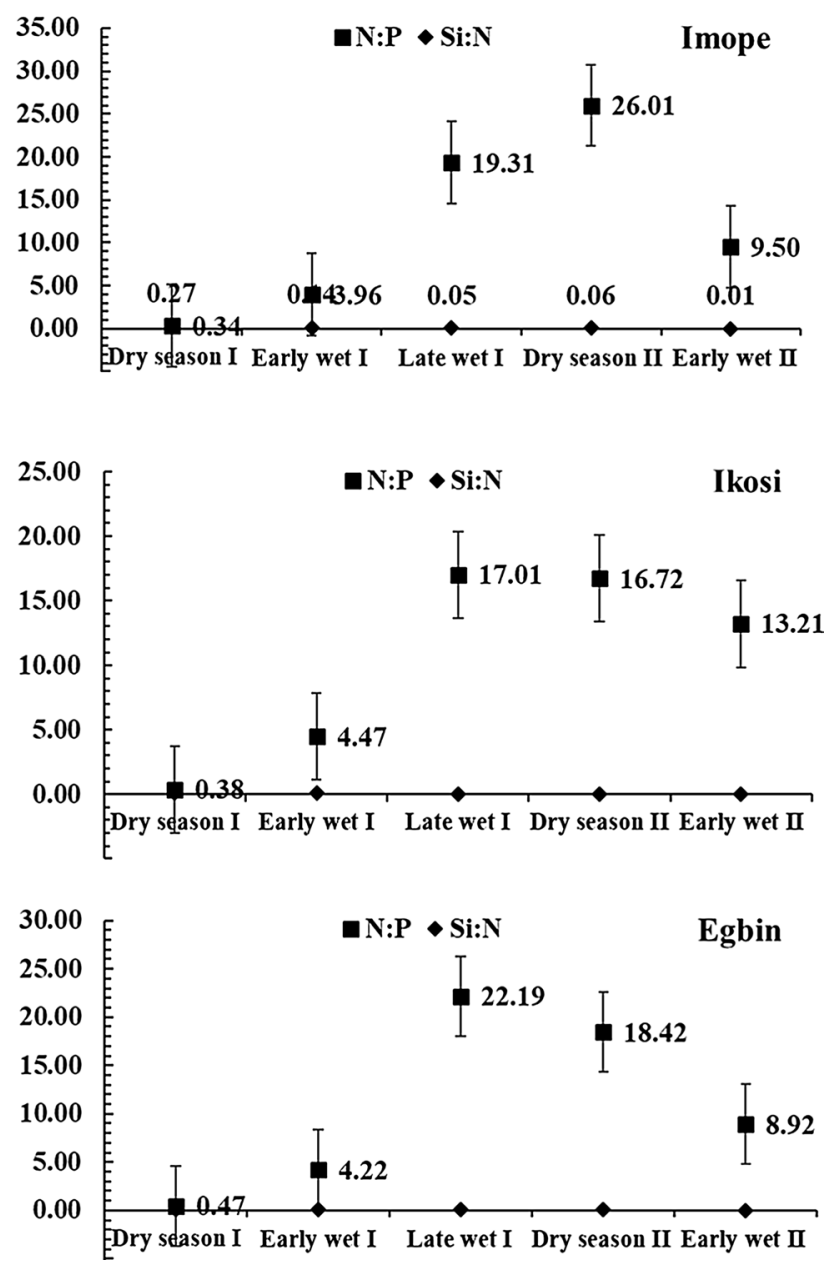

Fig. 4 Seasonal mean \pm SD of nutrient molar ratios at the three stations

(dry season I and II) when there was an incidence of cyanobacterial bloom. At Imope, the lowest diatom abundance (48\%) was recorded in April 2013, while cyanobacterial abundance was highest (22-47.0\%) in May, June and July 2013. At Ikosi, the lowest diatom abundance (37.0\%) was recorded in May 2013, while cyanobacterial abundance peaked $(\geq 98.0 \%)$ in January 2013, January 2014 and February 2014. Diatoms were lowest (5.0\%) in April 2013, while cyanobacteria were highest $(\geq 36.0 \%)$ in April and May 2013 at Egbin (Fig. 7). The prevalent bloom species were Anabaena circinalis, A. flos-aquae, A. limnetica and A. spiroides.

Twenty-three cyanobacterial taxa were recorded. Species richness was observed in the Order Nostocales with 10 taxa, Chroococcales with 5 taxa, Oscillatoriales with 4 taxa, Spirulinales with 2 taxa and Synechococaccales with 2 taxa, respectively (Table 1). Two cyanobacterial bloom episodes were observed at Ikosi, Epe lagoon, during the two annual cycles of the study when rainfall was low (Fig. 8). The first bloom began in January and
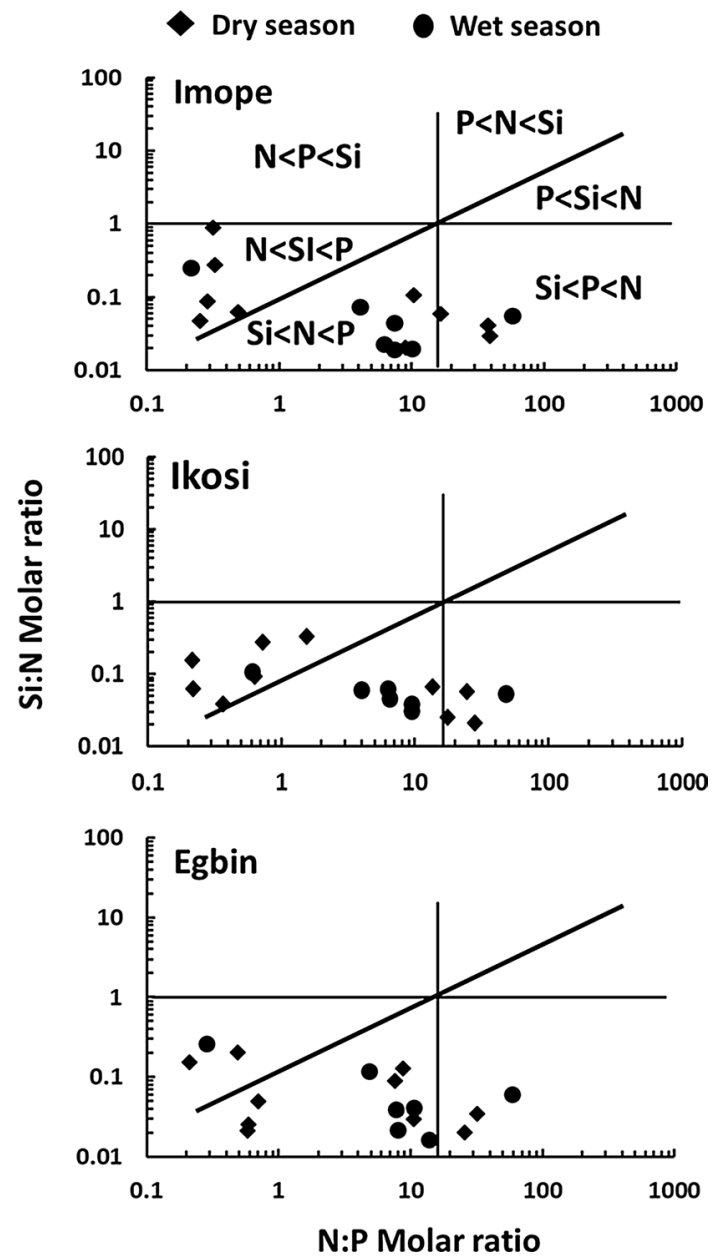

Fig. 5 Scatter diagrams of atomic nutrient ratios at Imope, Ikosi and Egbin during dry and wet season (November 2012-April 2014). Potential limitation for $\mathrm{N}, \mathrm{P}$ and $\mathrm{Si}$ based on their stoichiometric ratios is indicated by the number of data points in the quadrants. Vertical, horizontal and diagonal lines indicate Redfield et al. (1963) ratio (N/P), Brzezinski (1985) ratio (N/Si) and Agboola et al. (2013) aggregated ratio $(\mathrm{Si} / \mathrm{N} / \mathrm{P}=16: 16: 1)$, respectively

ended in February 2013, while the second bloom started in January 2014 and ended in March 2014. There was notable increase in phytoplankton density ( $>40,550$ cells/ $\mathrm{ml})$ and the dominance of cyanobacteria ( $>98 \%)$. During the first bloom episode, Anabaena circinalis $(30,000$ cell $/ \mathrm{ml}, 73.0 \%)$ and Anabaena limnetica $(10,000 \mathrm{cell} / \mathrm{ml}$, 24\%) were dominant, but the bloom collapsed in February 2013. Conversely, during the second bloom episode, Anabaena flos-aquae $(40,000 \mathrm{cell} / \mathrm{ml}, 99.0 \%)$ was dominant. Anabaena flos-aquae $(15,050$ cells $/ \mathrm{ml}, 27 \%)$, A. circinalis (30,000 cells $/ \mathrm{ml}, 53 \%)$ and Anabaena spiroides $(10,000$ cell/ml, 18\%) were recorded in February 2014 at Ikosi. The bloom collapsed in March 2014. At Ikosi, cyanobacterial cells were $\geq 98.0 \%$ of the total phytoplankton density which was higher $(2000 \mathrm{cell} / \mathrm{ml}-40,000 \mathrm{cell} / \mathrm{ml})$ than the alert level 1 ( $\geq 2000$ cells $/ \mathrm{ml}$ ) for raw waters (Bartram 

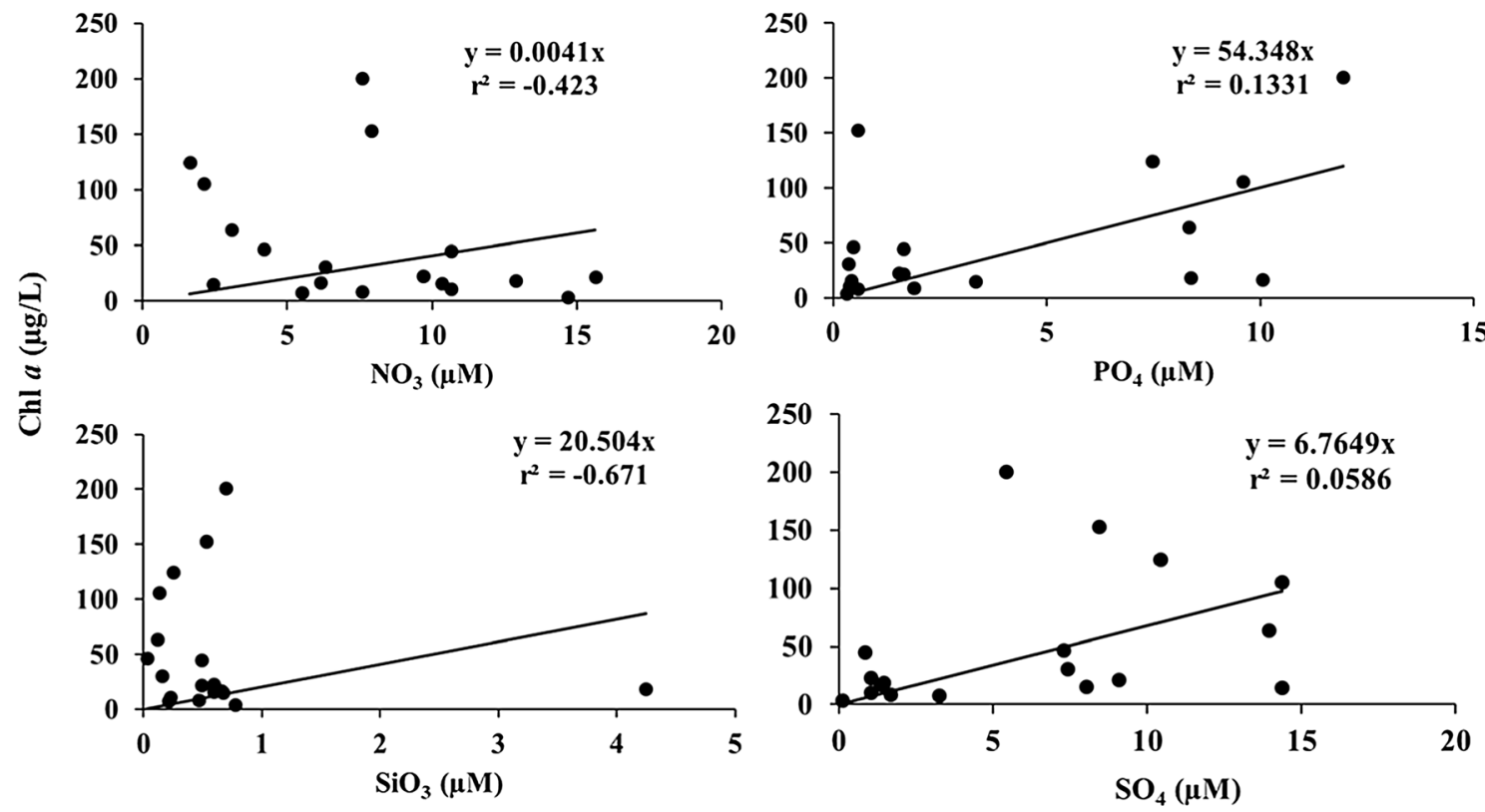

Fig. 6 Chlorophyll $a$ versus $\mathrm{NO}_{3}, \mathrm{PO}_{4}, \mathrm{SiO}_{3}, \mathrm{SO}_{4}$ at Ikosi (November 2012-April 2014). The regression equations are significant at $P>0.05$ and the correlation coefficient $r$ is given

et al. 1999) during the two bloom episodes. The cyanobacteria bloom did not reach alert level $2(\geq 100,000$ cells/ $\mathrm{ml}$ ) at the sampling sites during the study period (Fig. 9).

\section{Discussion}

\section{Environmental dynamics}

Seasonality and distribution of terrestrial and aquatic organisms in the tropics are determined by rainfall pattern (Webb 1960). Rainfall is a driving force in aquatic ecosystems of south-west, Nigeria (Olaniyan 1969; Oyenekan 1988; Nwankwo 1996) because it influences flow rate, mixing, dilution and nutrient recycling (Valiela et al. 2013). The observed lowest temperature $\left(\leq 27{ }^{\circ} \mathrm{C}\right)$ in the wet season (late wet I) might be attributed to the influx of cooler flood waters from wetlands, adjoining creeks and rivers. These assertions confirm temperature regimes in coastal lagoons of south-west, Nigeria (Onuoha and Vyverman 2010; Nwankwo et al. 2013). The low total suspended solids and total dissolved solids in the wet months agree with observations of Nwankwo (1996, 1997), Onyema and Nwankwo (2006), Adesalu and Nwankwo (2010) and Onuoha and Vyverman (2010) in coastal waters of south-west Nigeria. Flood water intrusion causes dilution, high flushing rate and low retention time during the rainy season, which is different from the situations in the dry season and the onset of the rainfall. $\mathrm{pH}$ indicated an acidic condition in certain occasion (July 2013) which could be attributed to the seepage of humic and fulvic acid exudates from surrounding wetlands (Nwankwo et al. 2013; Canini et al. 2013). The slightly acidic to neutral nature of Epe lagoon probably accounted for the dominance of Aulacoseira granulata at Epe during the off-bloom season. Talling and Talling 1965 associated the proliferation of Aulacoseira granulata to low $\mathrm{pH}$ in studies of central African lakes. The observed $\mathrm{pH}$ remained within the acceptable limits of 6.3-8.5 for inland waters (Antoine and Saadi 1982). At Ikosi, a pH range between 6.7 and 7.4 was found to correspond to the period of high prevalence of Anabaena flos-aquae, A. circinalis, Anabaena limnetica, Anabaena sphaerica and Anabaena spiroides.

Dissolved oxygen is dependent on water temperature and decreases as water temperature increases. Photosynthesis, respiration and other hydrological dynamics such as river influx, flushing rate and mixing influence dissolved oxygen levels in aquatic ecosystems (Watt 2000). In this study, dissolved oxygen and BOD were relatively low especially during the bloom episodes in the dry season. The relatively higher DO and BOD values that were observed during the rainy season might be due to mixing of surface water with atmospheric oxygen by current, wave action and river inflow. Chindah and Nduaguibe 2003 observed high dissolved oxygen levels attributed to current and wave action in a study of the Bonny river in Niger Delta.

In lotic fresh waters, Hynes (1960) suggested that BOD between $6.0 \mathrm{mg} / \mathrm{L}$ and $8.0 \mathrm{mg} / \mathrm{L}$ indicates moderate pollution while values greater than $8.0 \mathrm{mg} / \mathrm{L}$ indicate severe pollution. BOD values at Epe lagoon suggest that Epe lagoon is moderately to highly polluted during the wet season, owing 

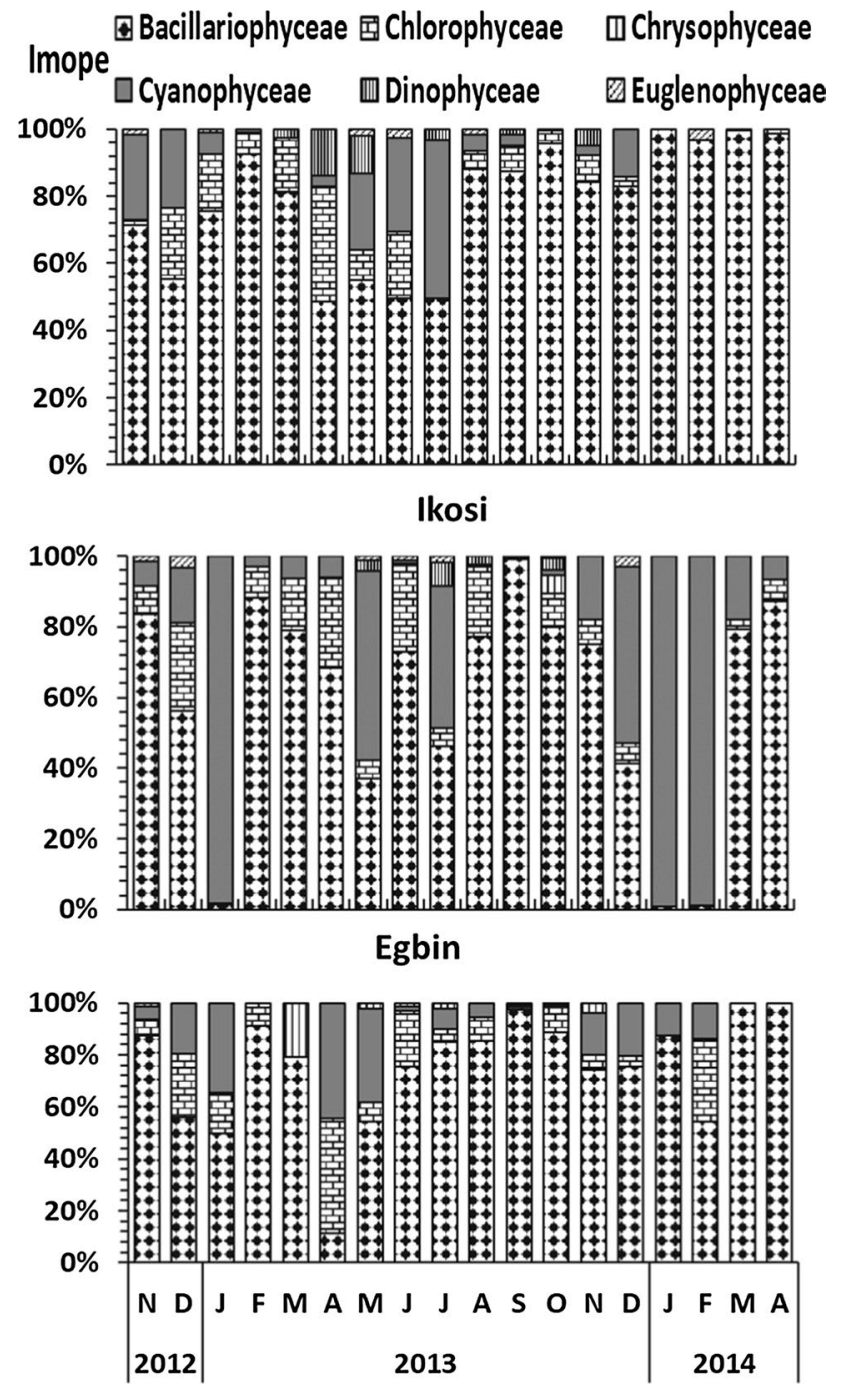

Fig. 7 Temporal distribution and relative abundance of the six phytoplankton groups observed at the three stations

to influx of land-originated pollutants. The acceptable limit of BOD set by the WHO (1978) for international water quality standards is $15.9-37.5 \mathrm{mg} / \mathrm{L}$ with warning limit of $18.9-34.9 \mathrm{mg} / \mathrm{L}$. An increase in the amount of organic materials in aquatic ecosystems results in high levels of COD (WHO 1978). COD values were high at Ikosi in January 2013 and February 2014, Imope in March 2014 and Egbin in April 2014. The observed higher values of COD at these sites during this period may be due to the collapse of the bloom and horizontal mixing of the surface water. There was no significant difference $(P>0.05)$ in water temperature, $\mathrm{pH}$, salinity and TDS across all the sampling sites, whereas significant difference $(P>0.05)$ was observed for total suspended solids which was high at the onset of the rainy season.

\section{Nutrients and molar ratios}

Nutrient concentrations and variations in stoichiometric nutrient ratio $(\mathrm{Si} / \mathrm{N}, \mathrm{N} / \mathrm{P}$ and $\mathrm{Si} / \mathrm{P})$ are influenced by rainfall, human activities (Elser et al. 2009; Yadav and Pandey 2018), internal nutrient cycling and regeneration (e.g. denitrification, nitrogen fixation) (Hudson et al. 1999). The rate of nitrogen and phosphorus cycling through sediment influences nitrogen or phosphorus limitation in aquatic ecosystems (Vitousek and Howarth 1991). In freshwater and coastal marine ecosystems, nitrogen is removed in sediments through denitrification (Knowles 1982; Seitzinger et al. 1984; Seitzinger 1988). Phosphorus is readily released from sediments through mineralization (Rowe et al. 1975; Boynton et al. 1982). In tropical waters of west Africa, nitrogen concentrations are mostly introduced through anthropogenic sources. The reduction of nitrogen and/or phosphorus inputs into aquatic systems can improve the quality of the water. Nutrient reduction effort can be challenging especially when it is introduced into the aquatic ecosystem through non-point sources such as agricultural run-off. The improvement of water quality may be slowed by internal loading of nutrients from sediments after external loading of nutrients is reduced (Søndergaard et al. 2003). Nutrient stoichiometry elaborates the role of resource availability in aquatic ecosystems (del Amo et al. 1997) as well as resource competition in phytoplankton (Tilman 1982). N/Si/P ratio of marine diatoms is about 16:16:1 (Redfield et al. 1963; Brzezinski 1985) and deviations from this ratio may result in nutrient limiting for phytoplankton (Hecky and Kilham 1988; Dortch and Whitledge 1992). Silicate was limiting $(\mathrm{Si} / \mathrm{N}<1)$ at the study sites, possibly resulting from the absence of tidal sea water influence in Epe lagoon, introduction of organic nitrogen and phosphates by flood water and agricultural run-off. Nutrient-laden influx from agricultural practices could result in increased levels of nitrate and phosphate, as well as relatively low or declining silicate concentrations (Justic et al. 1995b). Nwankwo (1996) attributed higher silicate values in the dry season to the cessation of flood water discharge and the influx of tidal sea water into the brackish Lagos lagoon. van Bennekom and Wetsteijn (1990) reported that $\mathrm{Si}$ concentration at the Rhine River remained constant during a long-term study. Comparably, Si concentrations were reduced by $50 \%$ during $1955-1987$ in the Mississippi River (Turner and Rabalais 1991). In this study, silicate values were higher than the threshold value $2 \mu \mathrm{M}$ (Justic et al. 1995a) at Imope $(\geq 2.31 \mu \mathrm{M})$ in February 2013 and at Ikosi $(\geq 4.24 \mu \mathrm{M})$ in March 2013. These values coincided with the lower cyanobacterial biomass at Imope in February 2013, the collapse of cyanobacterial bloom and the proliferation of diatoms (84.38\%) at Ikosi in March 2013 after the bloom regime (Fig. 7).

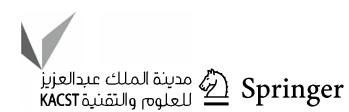


Table 1 Cyanobacterial species in Epe lagoon showing its occurrence frequency $(F \%)$ and the type of species $(\mathrm{R}$, rare, $F<10 \%$; C, common, $10 \%>F<50 \%$; CT, constant, $F>50 \%$ )

\begin{tabular}{|c|c|c|c|c|c|c|c|}
\hline \multirow{3}{*}{$\begin{array}{l}\text { Cyanobacteria species } \\
\text { Anabaena affinis Lemm. }\end{array}$} & \multirow{2}{*}{\multicolumn{2}{|c|}{$\frac{\text { Imope }}{F \%}$}} & \multirow{2}{*}{\multicolumn{2}{|c|}{$\frac{\text { Ikosi }}{F \%}$}} & \multirow{2}{*}{\multicolumn{2}{|c|}{$\frac{\text { Egbin }}{F \%}$}} & \multirow{3}{*}{$\begin{array}{l}\text { Order } \\
\text { Nostocales }\end{array}$} \\
\hline & & & & & & & \\
\hline & - & - & 5.6 & $\mathrm{R}$ & - & - & \\
\hline Anabaena azollae Strasburger & - & - & 5.6 & $\mathrm{R}$ & - & - & Nostocales \\
\hline Anabaena catenula Strasburger & - & - & 11.1 & $\mathrm{C}$ & 5.6 & $\mathrm{R}$ & Nostocales \\
\hline $\begin{array}{l}\text { Anabaena circinalis Rabenhorst ex Bornet } \\
\text { and Flahault }\end{array}$ & - & & 22.2 & $\mathrm{C}$ & - & - & Nostocales \\
\hline Anabaena flos-aquae (Lyng.) & - & - & 22.2 & $\mathrm{C}$ & 5.6 & $\mathrm{R}$ & Nostocales \\
\hline Anabaena limnetica Smith & - & - & 11.1 & $\mathrm{C}$ & - & - & Nostocales \\
\hline Anabaena sphaerica Bornet and Flahault & - & - & 5.6 & $\mathrm{R}$ & - & - & Nostocales \\
\hline Anabaena spiroides Lemm. & 11.1 & $\mathrm{C}$ & 27.8 & $\mathrm{C}$ & 27.8 & $\mathrm{C}$ & Nostocales \\
\hline Aphanocapsa delicatissima West and West & 5.6 & $\mathrm{R}$ & 16.7 & $\mathrm{C}$ & 16.7 & $\mathrm{C}$ & Synechococcales \\
\hline Chroococcus dispersus (Keiss) Lemm. & - & - & - & - & 5.6 & $\mathrm{R}$ & Chroococcales \\
\hline Chroococcus limneticus Lemm. & 5.6 & $\mathrm{R}$ & 16.7 & $\mathrm{C}$ & 33.3 & $\mathrm{C}$ & Chroococcales \\
\hline Chroococcus turgidus (Kützing) Nägeli & - & - & - & - & 5.6 & $\mathrm{R}$ & Chroococcales \\
\hline Merismopedia elegans Braun & 5.6 & $\mathrm{R}$ & 5.6 & $\mathrm{R}$ & 5.6 & $\mathrm{R}$ & Synechococcales \\
\hline Merismopedia glauca (Ehr) Nageli & 11.1 & $\mathrm{C}$ & - & - & - & - & Synechococcales \\
\hline Microcystis aeruginosa (Kützing) Kützing & 38.9 & $\mathrm{C}$ & 33.3 & $\mathrm{C}$ & 27.8 & $\mathrm{C}$ & Chroococcales \\
\hline Microcystis flos-aquae (Wittrock) Kirchner & 11.1 & $\mathrm{C}$ & 44.4 & $\mathrm{C}$ & - & - & Chroococcales \\
\hline Nostoc sp. & 5.6 & $\mathrm{R}$ & 11.1 & $\mathrm{C}$ & 5.6 & $\mathrm{R}$ & Nostocales \\
\hline Oscillatoria curviceps Agardh ex Gomont & 5.6 & $\mathrm{C}$ & - & - & - & - & Oscillatoriales \\
\hline Oscillatoria limosa (Roth) Ag. & 22.2 & $\mathrm{C}$ & 16.7 & $\mathrm{C}$ & 27.8 & $\mathrm{C}$ & Oscillatoriales \\
\hline Oscillatoria princeps Vaucher & 5.6 & $\mathrm{R}$ & 5.6 & $\mathrm{R}$ & 11.1 & $\mathrm{C}$ & Oscillatoriales \\
\hline Oscillatoria tenius Agardh & 11.1 & $\mathrm{C}$ & 11.1 & $\mathrm{C}$ & 16.7 & $\mathrm{C}$ & Oscillatoriales \\
\hline Spirulina laxa Smith & 16.7 & $\mathrm{C}$ & - & - & - & - & Spirulinales \\
\hline Spirulina major Kutzingii & - & - & 11.1 & $\mathrm{C}$ & - & - & Spirulinales \\
\hline
\end{tabular}

$\mathrm{NO}_{3}$ values $(\geq 1.45 \mu \mathrm{M})$ at the three sampling sites were higher than the threshold value $1 \mu \mathrm{M}$ (Justic et al. 1995a). The increase in nitrate levels during the wet season could be attributed to the introduction of floodwaters that contained organic materials from adjoining wetland and nutrient rich agricultural run-off due to poor farm practices. Of all the five seasonal partitions, low N/P was recorded during the dry season I (November 2012-February 2013), early wet I (March 2013-June 2013) and early wet II (March 2014-April 2014) during this study. The observation during the dry season I might be a consequence of faster utilization of nitrate by phytoplankton in aquatic environments, while low N/P during early wet season I and early wet season II might be a sign of the effect of high flushing rate and low retention time during this period. N/P was high $(\geq 16.72)$ at the three sites during the late wet season I (July 2013-October 2013) and dry season II (November 2013-February 2014). $\mathrm{PO}_{4}$ values $(\geq 0.18 \mu \mathrm{M})$ at the three sampling sites were higher than the threshold value $0.1 \mu \mathrm{M}$ (Justic et al. 1995a).

Rainfall values were high during the late wet season I which caused intense nutrient-laden flood water intrusion into the lagoon. However, the absence of rainfall in August 2013 possibly slowed flushing and increased residence time of the lagoon during this period. Flood water inflow influenced eutrophication in coastal waters because nitrate and phosphate from agricultural run-offs (fertilizers) are released (Qian et al. 2016). The resulting effect is the change in N/P, $\mathrm{Si} / \mathrm{P}$ and $\mathrm{Si} / \mathrm{N}$ leading to potential silicate limitation because of the increased nitrate and phosphate concentrations. The dry season II period was associated with reduced volume of freshwater inflow from adjoining river, less perturbation stress related to mixing, reduced flushing and higher residence time in the lagoon. This situation probably explained the high N/P ratio values and cyanobacterial bloom during this period. Relationships between riverine nutrient input, land based flood water and eutrophication in coastal waters have previously been reported in the Chesapeake Bay (Officer et al. 1984), the northern Adriatic Sea (Justic et al. 1987), some areas of the Baltic Sea (Andersson and Rydberg 1988), Mississippi river (Turner et al. 1998), Neuse River Estuary (Paerl 2006), Pearl River Estuary (Yin and Harrison 2008) and Kopački Rit floodplain (Mihaljevic and Stevic 2011).

Sources of sulphate in aquatic environments can be either natural or anthropogenic. Industrialization, burning of fossil fuel and agricultural practices contribute to sulphate availability in coastal ecosystems (Rhode et al. 1995; Zhao et al. 


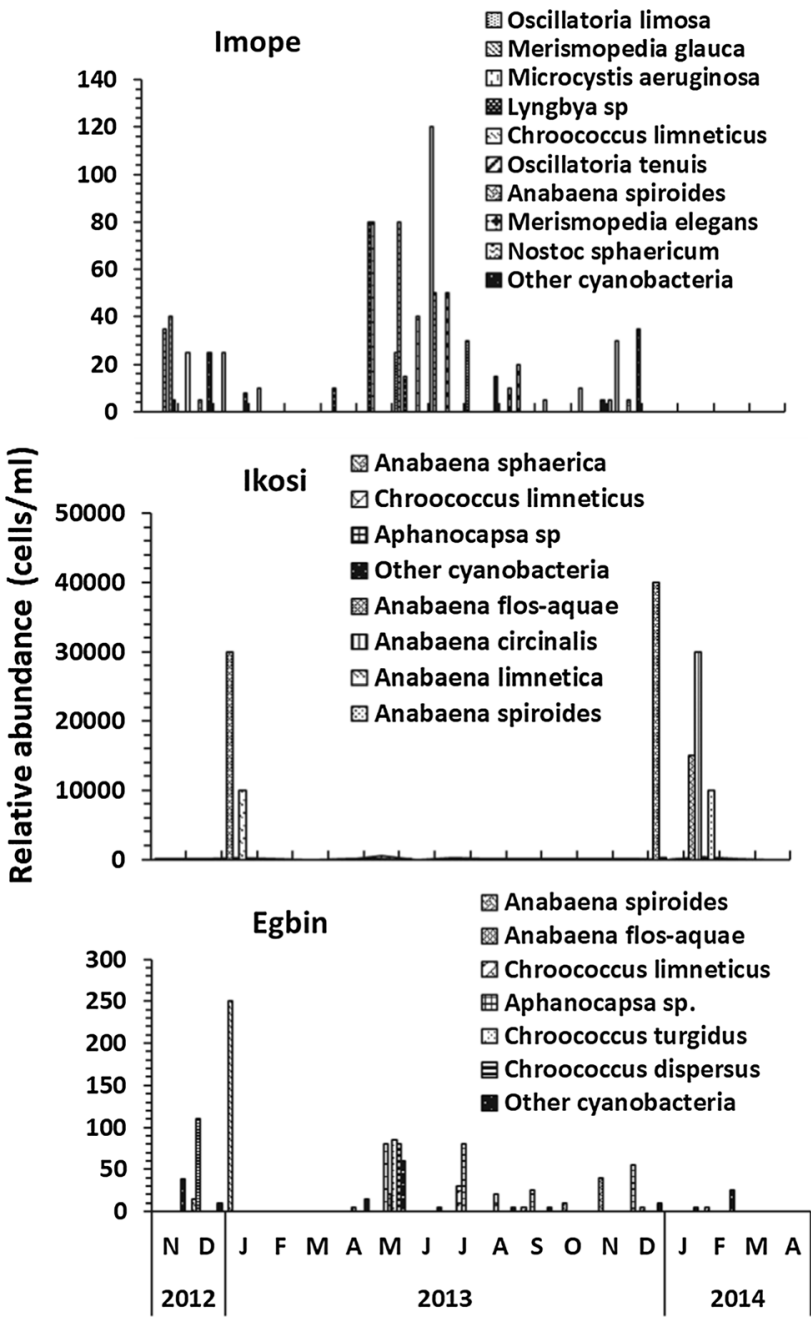

Fig. 8 Temporal distribution of cyanobacterial species composition observed at the three stations

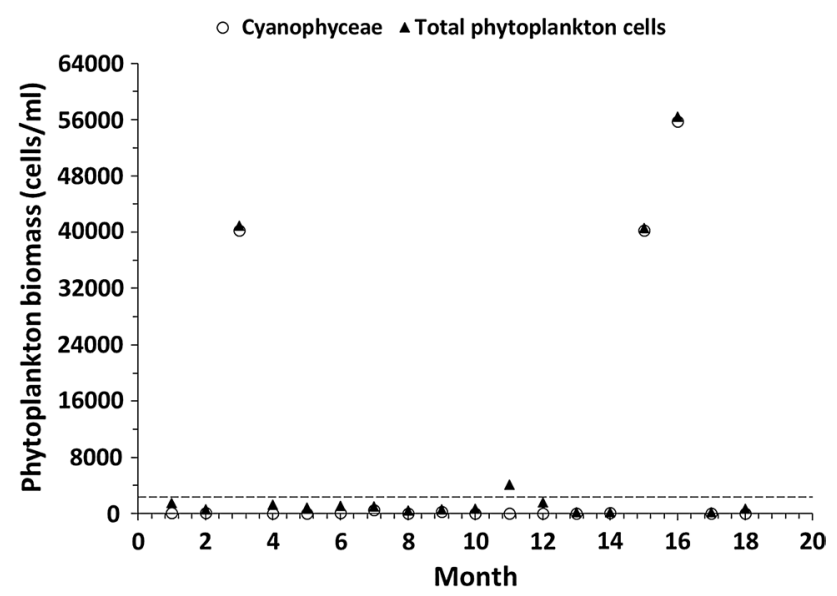

Fig. 9 Cyanobacterial cell abundance (cells/ml) and total phytoplankton (cells/ml) at Ikosi, Epe lagoon. Dashed line indicates alert level 1 (Bartram et al. 1999)
2003). Sulphate enters aquatic ecosystems through leachates from soil, precipitation, petroleum spill and ammonium sulphate fertilizers. Phytoplankton utilize sulphate for physiological and metabolic processes (Giordano et al. 2005) although little is known about its role in phytoplankton bloom. Sulphate concentrations regulate the flux of phosphorus from sediment to an extent. At low sulphate levels, phosphorus is usually adsorbed to sediment while high sulphate levels support the release of phosphorus to the water column (Caraco et al. 1989, 1990). Sulphate concentrations in this study were generally higher in the dry than the wet season because of the reduced flood water influx and longer retention time during the dry season. The presence of petroleum products in this lagoon could be the source of observed $\mathrm{SO}_{4}$.

\section{Phytoplankton dynamics and controlling factors}

Chlorophyll $a$ followed a seasonal trend and was closely related to phytoplankton abundance. Similarly, Suzuki et al. (2002) reported that low chlorophyll $a$ value implied limited phytoplankton growth in a turbid Mexican lagoon. The rise in chlorophyll $a$ during the dry season may be related to increased insolation, photosynthetic depth, retention time as well as less perturbation stress from flood waters. Flushing of planktonic microalgae by flood could lead to the low chlorophyll $a$ values in the rainy season. A single major rainfall peak in the dry season (January-February) and a minor peak in the late rainy season (August-November) were documented at Ikpoba reservoir, Edo state, Nigeria (Kadiri 1993).

The dynamics and seasonality of chlorophyll $a$ pointed to the interplay between phytoplankton growth and loss rate which are caused by multiple mechanisms in aquatic ecosystem (Cloern 1996). Phytoplankton population dynamics are dependent on changes in the proportion of dissolved $\mathrm{Si}, \mathrm{N}$ and P. Officer and Ryther (1980) hypothesized that decreasing $\mathrm{Si} / \mathrm{N}$ ratio may increase eutrophication by reducing the potential for diatom growth in favour of harmful phytoplankton species. Long-term decline in $\mathrm{Si} / \mathrm{P}$ ratios was responsible for significant blooms of non-siliceous algae in coastal waters worldwide (Smayda 1990).

Phytoplankton successional pattern at Ikosi showed a clear transition from diatom to cyanobacterial dominance in the dry season during the two annual cycles. The coincidence of the cyanobacterial bloom in the dry season could be attributed to higher insolation, water temperature, photosynthetic depth and increased stability of water (Fig. 10). Anabaena catenula, A. circinalis, A. limnetica and $A$. spiroides which are nitrogen-fixing cyanobacteria dominated the phytoplankton community during the bloom episode in the dry season I and II at Ikosi. The bloom episode during the dry season I coincided with low N/P ratio, possibly due to improved water stability and phosphorus

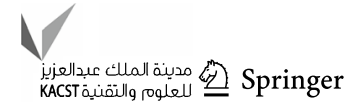




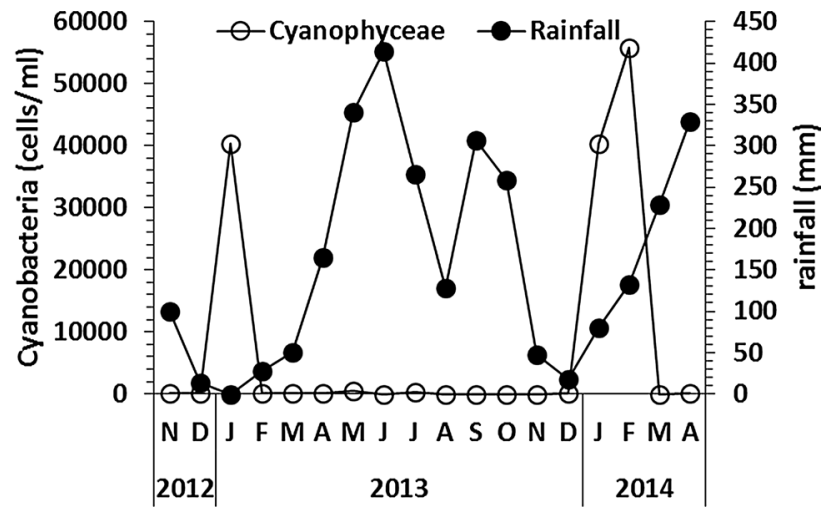

Fig. 10 Cyanobacterial blooms (cells/ml) and rainfall $(\mathrm{mm})$ at Ikosi part of Epe lagoon

being more available as a result of biogeological process and mineralization (Rowe et al. 1975). The prevalence of $\mathrm{N}$ fixing cyanobacteria is a response to nitrogen limitation in aquatic ecosystems (Paerl et al. 2014). In this study, higher nitrogen concentration $(\mathrm{N} / \mathrm{P}=16.7: 1)$ during the bloom episode in the dry season II may suggests an input from the surrounding wetland. In the tropics, rainfall controls physical, chemical and biological dynamics in aquatic ecosystem. Consequently, this might be the reason for the low nitrogen during the bloom episode I (January 2013) when there was no rainfall. However, rainfall values $(\geq 80.1 \mathrm{~mm})$ accounted for the nitrate availability during the bloom episode II (January and February 2014) which lasted longer because of the associated nutrient-laden river influx.

Despite the increased stability of the water column during the bloom episode I when there was no rainfall, the bloom duration was shorter than the bloom episode II. This suggests that in addition to optimal environmental conditions (light, temperature, stability etc.), riverine and land-based nutrient influx might be an important factor that influenced the bloom duration in the tropical aquatic environments.

\section{Eutrophication, cyanobacteria bloom and consequences}

A visible greenish colouration was seen on the surface water at Ikosi on three sampling occasions. The two cyanobacterial bloom regimes occurred in the dry season and were related to environmental conditions. The duration of the bloom was determined by the rainfall pattern which controlled nutrient influx, flushing rate and residence time. Higher insolation and improved stability of the lagoon during the dry months probably favoured the proliferation of $\mathrm{N}$ fixing cyanobacteria. Domestic waste discharge, agricultural run-off and poor sewage systems are sources of organic nutrient enrichment in coastal waters of Nigeria. Coastal lagoons are residual sink for large nutrient loading associated with anthropogenic and agricultural activities. These introductions cause an imbalance in the aquatic ecosystem which alter food chain that lead to loss of biodiversity and productivity (Nwankwo and Akinsoji 1992; Kevin et al. 2003). Nutrient loading has led to intensified eutrophication causing reoccurring algal bloom episodes including harmful species, accrual of organic matter and oxygen depletion (hypoxia and anoxia). In addition to eutrophication, climatic and hydrogeological factors such as rainfall pattern, flood, temperature rise, flow rate, river and storm water discharge influence anoxia and hypoxia conditions in aquatic ecosystems. The complex interactions of these environmental factors determine the magnitude of the temporal and spatial dynamics of algal blooms and oxygen depletion (Cloern 2001, Thomas and Litchman 2016). The complexity of these systems affects the physical, chemical and biological processes controlling the production and accumulation of organic matter, oxygen dynamics and nutrient cycling (Paerl 2006). DO depletion (anoxia and hypoxia) is one of the major consequences of eutrophication in coastal waters (Harrison et al. 2008). The variation between relatively high rates of oxygen consumption and low rates of oxygen introduction results in a decrease in DO levels. Very low or hypoxic conditions $(\mathrm{DO} \leq 2.6 \mathrm{mg} / \mathrm{L}$ ) were observed at the three sites in January 2013 and at Ikosi (DO $\leq 5 \mathrm{mg} / \mathrm{L})$ in January 2014 due to the bloom episode and subsequent oxygen utilization by microbial degradation of organic matter.

Anabaena catenula, A. circinalis, A. limnetica and A. spiroides were the bloom species observed in the lagoon. Some of these species have been reported to be potentially toxic. For instance, potentially toxic cyanobacteria Snowella fennica, Microcystis aeruginosa, Planktothrix agardhii and Anabaena circinalis were reported in Paso de las Piedras reservoir, Buenos Aires, Argentina (Fernández et al. 2015). Furthermore, blooms of Aphanizomenon, Dolichospermum, Nodularia and Phormidium have been documented in ecological studies of the Eurasian Arctic and Hypoarctic large river estuaries (Davydov and Patova 2017). In reference to the alert framework for cyanobacteria in coastal waters (Bartram et al. 1999), alert level 1 ( $\geq 2000$ cells/ml) was exceeded at Epe lagoon (Ikosi). Cyanobacterial biomass was high $(40,000$ cell $/ \mathrm{ml})$, almost reaching alert level 2 ( $\geq 100,000$ cells $/ \mathrm{ml}$ ). These observations call for an alarming concern and demand continuous environmental monitoring and management of this coastal lagoon.

\section{Conclusion}

The factors regulating the severity of algal blooms in aquatic ecosystems are complex. In this study, rainfall, anthropogenic activities along bordering wetlands and hydrodynamics are forcing factors which influence phytoplankton 
communities, nutrient dynamics and bloom development. The hypoxic conditions observed during the two bloom episodes reflect the vulnerability of the biological component of this lagoon. Rainfall controlled nutrient dynamics which triggered cyanobacterial bloom development and influenced the bloom duration. Nitrate, phosphate, sulphate and other environmental factors were related to the seasonality whereas silicate was relatively low. Blooms were dominated by potentially toxic species: Anabaena circinalis, A. flosaquae, A. limnetica and A. spiroides, and were related to nitrate dynamics. This study provides an important scientific information to the development of tools to assess, manage and mitigate risk of noxious bloom occurrences in tropical lagoons.

Acknowledgements We thank the department of Marine Sciences, University of Lagos, Nigeria, for their support during the study. Sandra C. Akagha acknowledges the support by the Organization for Women in Science for the Developing World (OWSD) and the Swedish International Development Cooperation Agency (Sida) postgraduate training fellowship (Grant No. 3240274102)

Funding This study was funded by Akagha Sandra Chinwendu.

\section{Compliance with ethical standards}

Conflict of interest The authors declare that they have no conflict of interest.

Open Access This article is licensed under a Creative Commons Attribution 4.0 International License, which permits use, sharing, adaptation, distribution and reproduction in any medium or format, as long as you give appropriate credit to the original author(s) and the source, provide a link to the Creative Commons licence, and indicate if changes were made. The images or other third party material in this article are included in the article's Creative Commons licence, unless indicated otherwise in a credit line to the material. If material is not included in the article's Creative Commons licence and your intended use is not permitted by statutory regulation or exceeds the permitted use, you will need to obtain permission directly from the copyright holder. To view a copy of this licence, visit http://creativecommons.org/licenses/by/4.0/.

\section{References}

Adesalu TA, Nwankwo DI (2010) Cyanobacteria of a tropical Lagoon, Nigeria. J Am Sci 6(11):1101-1107

Adesalu TA, Kunrunmi OA, Omoregie ME, Adeniyi-Martins O (2016) First record of bloom-forming cyanobacteria, Microcystis aeruginosa Kütz. and $M$. wesenbergiiKomárek (cyanophyta) incidence in Oyan Dam, Ogun State, South-West, Nigeria. J Aquat Sci 31(1A):1-10

Agboola JI, Uchimiya M, Kudo I, Osawa M, Kido K (2013) Seasonality and environmental drivers of biological productivity on the western Hokkaido coast, Ishikari Bay, Japan. Estuar Coast Shelf Sci 127:12-23

Akagha SC (2017) Phytoplankton of Epe and Lagos Lagoons, Nigeria. Niger J Bot 30:253-276
Akagha SC, Johansen JR, Nwankwo DI, Yin K (2019) Lagosinema tenuis gen. et sp. nov. (Prochlorotrichaceae, Cyanobacteria): a new brackish water genus from Tropical Africa. Fottea Olomouc 19(1):1-12

Akin-Oriola GA (2003) On the phytoplankton of Awba reservoir, Ibadan, Nigeria. Rev Biol Trop 51(1):99-106

American Public Health Association (2005) Standard methods for the examination of water and wastewater, 4th edn. American Public Health Association, Washington, p 1076

Anderson D, Glibert P, Burkholder JM (2002) Harmful algal blooms and eutrophication: nutrient sources, composition and consequences. Estuaries 25(4):562-584

Andersson L, Rydberg L (1988) Trends in nutrient and oxygen conditions within the Kattegat: effects on local nutrient supply. Estuar Coast Shelf Sci 26:559-579

Antoine SE, Saadi HA (1982) Limnological studies on the polluted Ashar Canal at Basra, Iraq. Revegeshydrobiologia 67:405-418

Arrigo KR (2005) Marine microorganisms and global nutrient cycles. Nature 437:349-355

Bartram J, Burch M, Falconer IR, Jones G, Kuiper-Goodman T (1999) Situation assessment, planning and management. In: Chorus I, Bartram J (eds) Toxic cyanobacteria in water. A guide to their public health consequences, monitoring and management. WHO, London, pp 179-209

Boynton WR, Kemp WM, Keefe CW (1982) A comparative analysis of nutrients and other factors influencing estuarine phytoplankton production. In: Kennedy VS (ed) Estuarine Comparisons. Academic Press, New York, pp 69-91

Brzezinski MA (1985) The Si:C:N ratio of marine diatoms: interspecific variability and the effect of some environment variables. J Phycol 15:305-311

Canini ND, Metillo EB, Azanza RV (2013) Monsoon-influenced phytoplankton community structure in a Philippine mangrove estuary. Trop Ecol 54(3):331-343

Caraco N, Cole JJ, Likens GE (1989) Evidence for sulfate-controlled phosphorus release from sediments of aquatic systems. Nature 341(316-3):I8

Caraco N, Cole JJ, Likens GE (1990) A comparison of phosphorus immobilization in sediments of freshwater and coastal marine systems. Biogeochemistry 9:277-290

Carmichael WW (1997) The Cyanotoxins. In: Callow JA (ed) Advances in botanical research, vol 47. Academic Press, London, pp 211-255

Carmichael W (2008) A world overview: one hundred twenty seven years of research on toxic cyanobacteria-where do we go from here? In: Hudnell HK (ed) Cyanobacterial harmful algal blooms-state of the science and research needs. Springer, Berlin, pp 105-120

Chindah AC, Nduaguibe U (2003) Effect of tank farm wastewater on water quality and periphyton of Lower Bonny River Niger Delta, Nigeria. J Niger Environ Soc 1(2):206-222

Chukwu LO, Nwankwo DI (2004) The impact of landbased pollution on the hydrochemistry and macrobenthic community of a tropical West African Creek. Ekologia 2(1-2):1-9

Cloern JE (1996) Phytoplankton bloom dynamics in coastal ecosystems: a review with some general lessons from sustained investigation of San Francisco Bay, California. Rev Geophys $34: 127-168$

Cloern JE (2001) Our evolving conceptual model of the coastal eutrophication problem. Mar Ecol Pollut Ser 210:223-253

Compère $\mathrm{P}$ (1976) Algues de la région du Lac Tchad. V-Chlorophycophytes (1ère partie). Cah. O.R.S.T.O.M., sér. Hydrobiologia 10:77-118

Compère $\mathrm{P}$ (1977) Algues de la région du Lac Tchad VII-Chlorophycophytes (3e partie: Desmidiées) (1). Cah. O.R.S.T.O.M., sér. Hydrobiologia 11:77-177

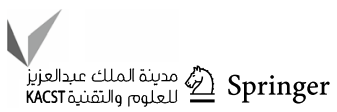


da Silva Brito MT, Duarte-Neto PJ, Molica RJR (2018) Cylindrospermopsisraciborskii and Microcystis aeruginosa competing under different conditions of $\mathrm{pH}$ and inorganic carbon. Hydrobiologia 815:253-266

Davydov D, Patova E (2017) The diversity of Cyanoprokaryota from freshwater and terrestrial habitats in the Eurasian Arctic and Hypoarctic. Hydrobiologia 811:119-137

del Amo Y, Le Pape O, Tréguer P, Quéguiner B, Ménesguen A, Aminot A (1997) Impacts of high-nitrate freshwater inputs on macrotidal ecosystems. I. Seasonal evolution of nutrient limitation for the diatom dominated phytoplankton of the Bay of Brest (France). Mar Ecol Prog Seres 161:213-224

Dortch Q, Whitledge TE (1992) Does nitrogen or silicon limit phytoplankton production in the Mississippi River plume and nearby regions? Cont Shelf Res 12:1293-1309

Downing JA, Watson SB, McCauley E (2001) Predicting Cyanobacteria dominance in lakes. Can J Fish Aquat Sci 58:1905-1908

Edwards M, Johns DG, Leterme SC, Svendsen E, Richardson AJ (2006) Regional climate change and harmful algal blooms in the northeast Atlantic. Limnol Oceanogr 52(2):820-829

Elser JJ, Andersen T, Baron JS, Bergström A, Jansson M, Kyle M, Nydick KR, Steger L, Hessen DO (2009) Shifts in lake N:P stoichiometry and nutrient limitation driven by atmospheric nitrogen deposition. Science 326:835-837

Fernández C, Estrada V, Parodi ER (2015) Factors triggering cyanobacteria dominance and succession during blooms in a hypereutrophic drinking water supply reservoir. Water Air Soil Pollut 226:73-86

Ferreira JG, Wolff WJ, Simas TC, Bricker SB (2005) Does biodiversity of estuarine phytoplankton depend on hydrology. Ecol Model 187:513-523

Giordano M, Norici A, Hell R (2005) Sulfur and phytoplankton: acquisition, metabolism and impact on the environment. New Phytol 166:371-382

Graham LE, Wilcox LW (2000) Algae. Prentice Hall, Upper Saddle River, $\mathrm{p} 640$

Hallegraeff GM, Bolch CJ (1992) Transport of dinoflagellate cysts in ships' ballast water: implications for plankton biogeography and aquaculture. J Plankton Res 14:1067-1084

Harrison PJ, Yin K, Lee JHW, Gan J, Liu H (2008) Physical-biological coupling in the Pearl River Estuary. Cont Shelf Res 28:1405-1415

Hecky RE, Kilham P (1988) Nutrient limitation of phytoplankton in freshwater and marine environments: a review of recent evidence on the effects of enrichment. Limnol Oceanogr 33:796-822

Hitzfeld BC, Höger SJ, Dietrich DR (2000) Cyanobacterial toxins: removal during drinking water treatment, and human risk assessment. Environ Health Perspect 108:113-122

Hudson JJ, Taylor WD, Schindler DW (1999) Planktonic nutrient regeneration and cycling efficiency in temperate lakes. Nature 400:659-661

Hynes HBN (1960) The biology of polluted waters. Liverpool University Press, Liverpool, p 202

Jackson JBC (2001) What was natural in the coastal oceans? Proc Natl Acad Sci USA 98:5411-5418

Jeppesen E, Jensen JP, Søndergaard M, Lauridsen T, Pedersen LJ, Jensen L (1997) Top-down control in freshwater lakes: the role of nutrient state, submerged macrophytes and water depth. Hydrobiologia 342:151-164

Justic D, Legovic T, Rottini-Sandrini L (1987) Trends in the oxygen content 1911-1984 and occurrence of benthic mortality in the northern Adriatic Sea. Estuar Coast Shelf Sci 25:435-445

Justic D, Rabalais NN, Turner RE, Dortch Q (1995a) Changes in nutrient structure of river-dominated coastal waters: stoichiometric nutrient balance and its consequences. Estuar Coast Shelf Sci 40:339-356
Justic D, Rabalais NN, Turner RE (1995b) Stoichiometric nutrient balance and origin of coastal eutrophication. Mar Pollut Bull 30:41-46

Kadiri MO (1993) Seasonal changes in the phytoplankton biomass of a shallow tropical reservoir. Niger J Bot 6:167-175

Kevin GS, Gregory JD, Gary JK (2003) Harmful algal blooms: causes, impacts and detection. J Ind Microbiol Biotech 30:383-406

Knowles R (1982) Denitrification. Microbial. Rev. 46:43-70

Komárek J, Anagnostidis K (1998) Cyanoprokaryota. I. Chroococcales. In: Ettl H, Gärtner G, Heynig H, Mollenhauer D (eds) Süsswasserflora von Mitteleuropa 19/1. Gustav Fischer, Jena-Stuttgart-Lübeck-Ulm

Komárek J, Anagnostidis K (2005) Cyanoprokaryota. II. Oscillatoriales. In: Büdel B, Krienitz L, Gärtner G, Schagerl M (eds) Süsswasserflora von Mitteleuropa 19/2. Elsevier/Spektrum, Heidelberg

Komárek J, Fott B (1983) Chlorophyceae (Grunalgen). OrdnungChlorococcales. Die Binnengewässer, Stuttgart

Krammer K, Lange-Bertalot H (1986) Bacillariophyceae. 1. Teil: Naviculaceae. Suswasserflora von Mitteleuropa 2/1: I-XVI, $1-876$

Krammer K, Lange-Bertalot H (1988) Bacillariophyceae. 2. Teil: Bacillariaceae, Epithemiaceae, Surirellaceae. Suswasserflora von Mitteleuropa 2/2:I-XI, 1-596

Krammer K, Lange-Bertalot H (1991b) Bacillariophyceae. 4. Teil: Achnanthaceae, kritischeErganzungenzuNavicula (Lineolatae) und Gomphonema. GesamtliteraturverzeichnisTeil 1-4. Suswasserflora von Mitteleuropa 2/4:I-IX, 1-437

Krammer K, Lange-Bertalot H (2000) Bacillariophyceae 5. English and French translation of the keys. Süsswasserflora von Mitteleuropa, Band 2/5, Berlin

Krammer K, Lange-Bertalot H, UnterMitarbeit von Hakansson H, Norpel M (1991a) Bacillariophyceae. 3. Teil: Centrales, Fragilariaceae, Eunotiaceae. Suswasserflora von Mitteleuropa 2/3: I-XIII, 1-576

Kusemiju K (1988) Strategies for effective management of water hyacinth in the creeks and lagoons of south-western Nigeria. In: Proceedings of the international on water Hyacinth, Lagos, pp 39-45

Lackey JB (1938) The manipulation and counting of river plankton and changes in some organism due to formalin preservation. US Public Health Rep 63:2080-2093

Li W, Qin B (2019) Dynamics of spatiotemporal heterogeneity of cyanobacterial blooms in large eutrophic Lake Taihu, China. Hydrobiologia 833:81-93

Litchman E (2007) Resource competition and the ecological success of phytoplankton. In: Knoll AH, Falkowski PG (eds) Evolution of primary producers in the sea. Elsevier Science, New York, pp 351-375

Litchman E, de Tezanos PP, Edwards KF, Klausmeier CA, Kremer CT, Thomas MK (2015) Global biogeochemical impacts of phytoplankton: a trait-based perspective. J Ecol 103:1384-1396

Malone TC (1977) Environmental regulation of phytoplankton productivity in the lower Hudson estuary. Estuar Coast Mar Sci 5:157-171

Matthews MW, Bernard S (2015) Eutrophication and cyanobacteria in South Africa's standing water bodies: a view from space. S Afr J Sci 111(5/6): 1-8

Mihaljević M, Stevic F (2011) Cyanobacterial blooms in a temperate river-floodplain ecosystem: the importance of hydrological extremes. Aquat Ecol 45:335-349

Nwankwo DI (1993) Cynobacteria bloom species in Coastal Waters of South Western Nigeria. Archiv Hydrobiologie 90:533-542

Nwankwo DI (1996) Phytoplankton diversity and succession in Lagos Lagoon, Nigeria. Archiv Fur Hydrobiologie 135(4):529-542 
Nwankwo DI (1997) A first list of Dinoflagellates (Pyrrophyta) from Nigerian coastal waters (creeks, estuaries, Lagoons). Polskie Archiwum Hydrobilogii 44(3):313-321

Nwankwo DI (1998) Seasonal changes in phytoplankton population and diversity in Epe Lagoon, Nigeria. Acta Hydrobiologia 10(2):83-92

Nwankwo DI, Akinsoji A (1992) Epiphyte community on water hyacinth, Eichhorniacrassipes(Mart.) Solms in coastal waters of South-Western Nigeria. Archiv Fur Hydrobiologia 24(4):501-511

Nwankwo DI, Nwachukwu SCU, Akpata TVI (1999) The hydrology and hydrobiology of Owo River, Lagos State, Nigeria. Niger J Bot 12(2):109-114

Nwankwo DI, Adesalu TA, Amako CC, Akagha SC, Keyede JD (2013) Temporal variations in water chemistry and chlorophyll- $a$ at the Tomaro creek Lagos, Nigeria. J Ecol Nat Environ 5(7):144-151

Officer CB, Ryther JH (1980) The possible importance of silicon in marine eutrophication. Mar Ecol Progr Ser 3:83-91

Officer CB, Biggs RB, Taft JL, Cronin LE, Tyler M, Boynton WR (1984) Chesapeake Bay anoxia: origin, development and significance. Science 223:22-27

Ojolowo SK, Onifade V (2016) Assessing contemporary solid waste management practices in Lagos metropolis, Nigeria. J Environ Stud 9:29-46

Olaniyan CIO (1969) The seasonal variation in the hydrobiology and total plankton of the Lagoons of South western, Nigeria. Niger J Sci 3:101-129

Onuoha PC, Vyverman W (2010) Hydrochemistry and plankton dynamics of Eutrophic tropical lagoon. Nat Sci 8(9):140-149

Onyema IC, Nwankwo DI (2006) The epipelic assemblage of a polluted estuarine creek in Lagos, Nigeria. Pollut Res 25(3):459-468

Onyema IC, Nwankwo DI (2009) An incidence of substratum discolouration in a tropical West African Lagoon. J Am Sci 5(1):44-48

Onyema IC, Otudeko OG, Nwankwo DI (2004) The distribution and composition of plankton around a sewage disposal site at Iddo, Nigeria. J Sci Res Dev 7:11-24

Oyenekan JA (1988) Benthic macrofaunal communities of Lagos Lagoon, Nigeria. Niger J Sci 21:45-51

Paerl HW (2006) Assessing and managing nutrient-enhanced eutrophication in estuarine and coastal waters: interactive effects of human and climatic perturbations. Ecol Eng 26:40-54

Paerl HW, Huisman J (2008) Blooms like it hot. Science 320(5872):57-58

Paerl HW, Otten TG (2013) Harmful cyanobacterial blooms: causes, consequences, and controls. Microb Ecol 65(4):995-1010

Paerl HW, Whitall DR (1999) Anthropogenically-derived atmospheric nitrogen deposition, marine eutrophication and harmful algal bloom expansion: is there a link? Ambio 28:307-311

Paerl HW, Xu H, Hall NS, Zhu G, Qin B, Wu Y, Rossigno KL, Dong L, McCarthy MJ, Joyner AR (2014) Controlling cyanobacterial blooms in hypertrophic Lake Taihu, China: will nitrogen reductions cause replacement of non- $\mathrm{N}_{2}$ fixing by $\mathrm{N}_{2}$ fixing taxa? PLoS ONE 9(11):e113123. https://doi.org/10.1371/journ al.pone. 0113123

Paerl HW, Otten TG, Kudela R (2018) Mitigating the expansion of harmful algal blooms across the freshwater-to-marine continuum. Environ Sci Technol 52:5519-5529. https://doi.org/10.1021/acs. est.7b05950

Patrick R, Reimer CW (1966) The diatoms of the United States exclusive of Alaska and Hawaii. Monographs. Academy of Natural Science, Philadelphia

Patrick R, Reimer CW (1975) The diatoms of the United States exclusive of Alaska and Hawaii. Entomoneidaceae, cymbellaceae, gomphonemaceae, epithemiaceae. Academy of Natural Sciences, Philadelphia
Peretyatko A, Teissier S, De Backer S, Triest L (2010) Assessment of the risk of cyanobacterial bloom occurrence in urban ponds: probabilistic approach. Int J Limnol 46:121-133

Prescott GW (1961) Algae of the Western Great lakes area. Brown Company Publ, Dubuque

Prescott GW (1973) Algae of the Western Great lakes area. Brown Company Publ, Dubuque

Prescott GW (1975) How to know the freshwater Algae. Brown Company Publisher, Dubuque, p 348

Prescott GW (1979) How to know the freshwater algae. The pictured key nature series

Prescott GW (1984) How to know the freshwater Algae, 3rd edn. Wm. C. Brown Company Publication, Dubuque

Qian K, Liu X, Chen Y (2016) Effect of hydrological variability on diatom distribution in Poyang Lake, China. Chin J Oceanogr Limnol 35:174-184

Rabalais NN, Nixon SW (2002) Dedicated issue: nutrient overenrichment in coastal waters: global patterns of cause and effect. Estuaries 25:639

Redfield AC, Ketchum BH, Richards FA (1963) The influence of organism on the composition of seawater. Sea 2:26-77

Reynolds CS (2006) Ecology of phytoplankton. Cambridge University Press, Cambridge

Rhode H, Langner J, Gallardo L, Kjellstrom E (1995) Global scale transport of acidifying pollutants. Water Air Soil Pollut $85: 37-50$

Round FE (1981) The ecology of algae. Cambridge University Press, Cambridge

Rowe GT, Clifford CH, Smith KL, Hampton PL (1975) Benthic nutrient regeneration and its coupling to primary productivity in coastal waters. Nature 225:215-217

Sanchis D, Carrasco D, Padilla C, Leganes F, Fernandez-Valiente E, del Campo FF, Quesada A (2002) Spatial and temporal heterogeneity in succession of cyanobacterial blooms in a Spanish reservoir. Ann Limnol Int J Lim 38:173-183

Sandrini G, Ji X, Verspagen JM, Tann RP, Slot PC, Luimstra VM, Schuurmans JM, Matthijs HCP, Huisman J (2016) Rapid adaptation of harmful cyanobacteria to rising $\mathrm{CO}_{2}$. Proc Natl Acad Sci 113(33):9315-9320

Seitzinger SP (1988) Denitrification in freshwater and coastal marine ecosystems: ecological and geochemical significance. Limnol Oceanogr 33:702-724

Seitzinger SP, Nixon SW, Pilson MEQ (1984) Denitrification and nitrous oxide production in a coastal marine ecosystem. Limnol Oceanogr 29:79-83

Shapiro J (1973) Blue-green algae: why they become dominant. Science 179:382-384

Shapiro J (1997) The role of carbon dioxide in the initiation and maintenance of blue-green dominance in lakes. Freshw Biol 37:307-323

Smayda TJ (1990) Novel and nuisance phytoplankton blooms in the sea: evidence for global epidemic. In: Sundstrom B, Edler R, Graneli E, Anderson DM (eds) Toxic marine phytoplankton. Elsevier Science, New York, pp 29-40

Sommer U (1989) The role of competition for resources in plankton succession. In: Sommer U (ed) Plankton ecology: succession in plankton communities. Springer, New York, pp 57-106

Søndergaard M, Jensen JP, Jeppesen E (2003) Role of sediment and internal loading of phosphorus in shallow lakes. Hydrobiologia 506:135-145

Strickland JDH, Parsons TR (1972) A practical handbook of seawater analysis, 2nd edn. Fisheries Research Board of Canada, Ottawa, p 328

Suzuki MN, Figueiredo RO, Castro SC, Silva CF, Pereira EA, Silva JA, Aragon GT (2002) Sand bar opening in a coastal lagoon (Iquipari) in the northern region of Rio de Janeiro

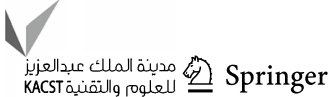


state: hydrological and hydrochemical changes. Braz J Biol 62(1):51-62

Talling JF, Talling IB (1965) The chemical composition of African Lakes. Int Rev Hydrobiol 50:421-463

Thomas MK, Litchman E (2016) Effects of temperature and nitrogen availability on the growth of invasive and native cyanobacteria. Hydrobiologia 763:357-369

Tilman D (1982) Resource competition and community structure. In: May RM (ed) Monographs in population biology, vol 17. Princeton University Press, Princeton

Turner RE, Rabalais NN (1991) Changes in Mississippi River water quality this century-implications for coastal food webs. BioScience 41:140-147

Turner RE, Qureshi N, Rabalais NN, Dortch Q, Justic D, Shaw RF, Cope J (1998) Fluctuating silicate:nitrate ratios and coastal plankton food webs. Proc Natl Acad Sci USA 95:13048-13051

Uwadiae RE (2010) An inventory of the benthic macrofauna of Epe lagoon, south-west Nigeria. J Sci Res Dev 12:161-171

Valiela I, Giblin A, Barth-Jensen C, Harris C, Stone T, Fox S, Crusius J (2013) Nutrient gradients in Panamanian estuaries: effects of watershed deforestation, rainfall, upwelling, and within-estuary transformations. Mar Ecol Prog Ser 482:1-15

van Bennekom AJ, Wetsteijn FJ (1990) The winter distribution of nutrients in the southern bight of the North Sea (1961-1978) and in the estuaries of the Scheldt and the Rhine/Meuse, Netherlands. J Sea Res 25:75-87

Van Dolah FM (2000) Marine algal toxins: origins, health effects, and their increased occurrence. Environ Health Perspect 108:133-141

Vanderploeg HA, Liebig JR, Carmichael WW, Agy MA, Johegen TH, Fahnenstiel GL, Nalepa TF (2001) Zebra mussel (Dreissenapolymorpha) selective filtration promoted toxic Microcystis blooms in Saginaw Bay (Lake Huron) and Lake Erie. Can J Fish Aquat Sci 58:1208-1221

VanLandingham SL (1982) Guide to the identification and environmental requirements and pollution tolerance of freshwater blue-green algae (cyanophyta). U.S. Environmental Protection Agency, EPA-60

Vitousek PM, Howarth RW (1991) Nitrogen limitation on land and in the sea: how can it occur? Biogeochemistry 13:87-115
Vogt JC, Albach DC, Palinska KA (2017) Cyanobacteria of the Wadden Sea: seasonality and sediment influence on community composition. Hydrobiologia 811(1):103-117

Watt MK (2000) A hydrologic primer for New Jersey Watershed Management (Water-Resources Investigation Report 00-4140). U.S. Geological Survey, West Trenton

Webb JE (1960) Biology in the tropics. Nature 188(4151):617-619

Wetzel RG (2001) Limnology: Lake and River Ecosystems, 3rd edn. Academic Press, San Diego

Willame R, Jurczak T, Iffly JF, Kull T, Meriluoto J, Hoffmann L (2005) Distribution of hepatotoxic cyanobacterial blooms in Belgium and Luxembourg. Hydrobiologia 551:99-117

Wołowski K, Hindak F (2005) Atlas of euglenophytes. VEDA, Bratislava, p 136

World Health Organization (1978) Water quality surveys. A guide for the collection and interpretation of water quality data. Studies and reports in hydrology, No. 23, United Nations Educational Scientific and Cultural Organization, Paris

Xu J, Ho AYT, Yin K, Yuan X, Anderson DM, Lee JHW, Harrison PJ (2008) Temporal and spatial variations in nutrient stoichiometry and regulation of phytoplankton biomass in Hong Kong waters: influence of the Pearl River outflow and sewage inputs. Mar Poll Bull 57:335-348

Yadav A, Pandey J (2018) The pattern of N/P/Si stoichiometry and ecological nutrient limitation in Ganga River: up- and downstream urban influences. Appl Water Sci 8:1-12

Yin K, Harrison PJ (2008) Nitrogen over enrichment in subtropical Pearl River estuarine coastal waters: possible causes and consequences. Cont Shelf Res 28:1435-1442

Zar JH (1999) Biostatistical analysis, 4th edn. Prentice-Hall, Englewood Cliffs, New Jersey

Zhao FJ, Knights JS, Hu ZY, McGrath SP (2003) Stable isotope ratio indicates long-term changes in sulfur deposition in the broadbalk experiment since 1845. J Environ Qual 32:33-39

Publisher's Note Springer Nature remains neutral with regard to jurisdictional claims in published maps and institutional affiliations. 